\title{
Discerning Calvin's pastoral care from his letters
}

\begin{abstract}
Author:
Raymond Potgieter ${ }^{1}$

Affiliation:

${ }^{1}$ Department of Theology,

North-West University,

Potchefstroom Campus,

South Africa

\section{Correspondence to:}

Raymond Potgieter

Email:

ray@csmdist.com

Postal address:

PO Box 19491, Noordbrug

2522, South Africa

Dates:

Received: 11 Apr. 2014

Accepted: 17 June 2014

Published: 09 Dec. 2014

How to cite this article:

Potgieter, R., 2014,

'Discerning Calvin's pastoral

care from his letters', In die

Skriflig 48(1), Art. \#1830,

8 pages. http://dx.doi.

org/10.4102/ids.v48i1.1830

Copyright:

C 2014. The Authors.

Licensee: AOSIS

OpenJournals. This work is

licensed under the Creative

Commons Attribution

License.
\end{abstract}

\section{Read online:}

Scan this QR code with your smart phone or mobile device to read online.
The same acuity that is evident in John Calvin's theological writings accompanied his correspondence. Calvin's mission was not to support God, but to honour him. Divine revelation and the glory of God underlie the content of his letters. The audacious confidence with which he writes, reveals his utter reliance upon the veracity of Scripture, which understanding must be conveyed through sound teaching. Yet, his letters are not inundated with scriptural references or quotes in the fashion of a medical prescription. Rather the connection between Scripture and writing for Calvin were twofold: it lies in the foundations of sound theology applied pastorally. This undergirded his pastoral care. To bring that across in his correspondence with Duchess Renata Ferrara, he followed basic doctrinal principles, evident from many of his letters applied pastorally to the recipient(s) of the letter.

Calvyn se pastorale benadering soos waargeneem in sy briewe. Dieselfde pastorale noukeurigheid wat duidelik in Johannes Calvyn se teologiese geskrifte waarneembaar is, kom ook in sy korrespondensie voor. Calvyn se oogmerk was nie bloot om God te eer nie, maar om Hom te verheerlik. Die inhoud van sy briewe reflekteer sowel die openbaring as die heerlikheid van God. Hy skryf met waagmoed en 'n selfversekerdheid wat sy vertroue in die waarheid van die Skrif weerspieël en wat deur Skrifgetroue onderrig oorgedra moet word. Tog maak hy nie in sy briewe op oordrewe wyse van teksverwysings of aanhalings gebruik om sy teologie te staaf nie. Die verband tussen die Skrif en sy skryfwerk was eerder vir Calvyn 'n tweeledige saak: dit berus naamlik op gesonde teologie wat pastoraal toegepas word. Dit blyk derhalwe uit baie van sy briewe, soos dié aan die Hertogin Renata Ferrara, dat hy die metode volg om basiese dogmatiese leerstellings in sy korrespondensie uit te lê en met pastorale sorg toe te pas.

\section{Introduction}

Although letter writing has been part of the progress of civilisation for the past 500 years there is some doubt about the continuing practices of the 'art of letter writing ${ }^{\prime 1}$ (Garfield 2013). Amongst the values extolled by Garfield (2013:21) are the following: 'There is an intrinsic integrity about writing letters that is lacking from other forms of written communication.' We recall the tragic love story and counselling of Abelard and Heloise in the Middle Ages because of the extant letters ${ }^{2}$ (Garfield 2013:75ff.). Calvin's letters are part of the volumes of correspondence of the reformation generally called Corpus Reformatorum. Most famously, it also includes the works ${ }^{3}$ of Philip Melanchthon and Huldrych Zwingli. However, it has never been easily accessible to the general English reader as most of the texts are in Latin, German or French and because most of the publications are scarce.

The impact of Calvin's correspondence cannot be underestimated. His writings circulated in every country of Europe, and he was a second-generation ${ }^{4}$ reformer (Fisher 1900:192). He was respected as an oracle (Beza 1836:95). His influence extended to include princes, nobles and principal leaders of the Reformation (Fisher 1900:236-237) - not only because of his wisdom, but for the insights his counsel brought to bear on matters enquired of him (Fisher 1900:235-237). An insight provided by Johnson (1900) to understand Calvin is that his emphasis upon the truth of the word of God was the following:

. error took the place of truth and Calvin loved truth, and error rent the body of Christ, the church, and

so dishonoured the Redeemer God, and Calvin loved God with all his heart. (pp. 65-66)

Baker (2011:152) is more optimistic suggesting that literary blogs are the substitutes of hard-copy letter writing.

2.Garfield (2013:79 ff.) deals with the controversy of the discovery of 15th-century letters between Abelard and Heloise.

3.Philip Melanchthon, Opera Quae Supersunt Omnia (CO) (n.d., vol. 1-28); loannis Calvini, CO (n.d., vol. 29-87); Huldreich Zwinglis, Sämtliche Werke, vol. 88-101. Calvin's 59 volumes were printed by C.A. Schwetschke and Son in Brunswick and Berlin (1863-1900) and again in New York and London by Johnson Reprints in 1964. A number of books supplement the Opera, correcting errors and adding again in New York and London by Johnson Reprints in 1964. A number of books supplement the Opera, correcting errors
omitted works (cf. Lane 1987). The Opera (n.d.) is now available on the net for downloading at the Hekman Library site.

4.Lefèvre was regarded as the father of the reformation in France (Fisher 1900:196). Calvin met him at the Court of Margaret, queen of Navarre, on the journey fleeing from Paris after Nicholas Cop's speech to the university. 
Calvin did not only stand up against the error of Roman Catholicism, but also against error in Protestantism, and it is this spirit of activism that he also brought to bear in his correspondence. Calvin's counselling of individuals by letter must be seen separately from the actual pastoral involvement he had with the congregation in Geneva, adequately attested to by Witte and Kingdon (2005). One of the observations about his letters is: 'If only Calvin could have made his requests short and to the point instead of encasing them in sermons of many pages' (Barton 1989:124).

If his letters seem harsh at times it must be understood in terms of his zeal for truth and his love for God and the church; he is ever the pastor of the flock. ${ }^{5} \mathrm{He}$ is not concerned about power, but about knowledge of God, the basis of truth, negating any thought of an exchange of truth for the sake of compromise (Beza 1836:86-88). Notwithstanding, this attitude necessitated careful theological judgement and a rigorous discernment applied exegetically to scriptural passages so as to maintain the truth of the Bible, but also the truth in dealing with fallen persons. ${ }^{6}$ At the end of his life, Calvin entrusted his letters to Theodore Beza (1519-1605) suggesting their possible publication ${ }^{7}$ so as to usefully serve the church (Greef 2008:198). These comments are therefore helpful in coming to his correspondence for the same man theologian, scholar, counsellor, author, pastor - authored the letters that are still available today. Bonnet's (2009:9, vol. 4) chronological collection spans letters from Calvin's earliest days to his deathbed.

To establish the outline of general guidelines in Calvin's letter writing, ${ }^{8}$ some of his letters to Renata, the Duchess of Ferrara (1510-1575) will be compared. Chronologically they span most of his active life as theologian and pastor from October 1541 to 04 April 1564. The letters cover some 23 years and will reveal some insights into the form and development of his correspondence and theology. A different way of coming to the same end would be to group Calvin's letters in some chronological form or even to thematically lump the same type of letters under a single heading such as 'letters to those persecuted for their faith'. The choice of the aforementioned lies in that this selection of letters to the Duchess of Ferrara will show something of Calvin's pastoral side and of his manner and approach in writing to women in general. However, it should also show how the guidelines of God's Word applied equally to men and women, favouring neither. Favouring will only be referred to in passing in this article.

5.This is the basis of Johnson's argument in the matter of Servetus, 'The controversy with Servetus: an illustration of Calvin's honour of God's word and the unity of the Church' (Johnson 1900:78-80, italics in the original).

6.For instance, of the book of Psalms, he says, 'I have been accustomed to call this book, I think not inappropriately, "An anatomy of all the parts of the soul" for there is not an emotion of which any one can be conscious that is not here represented as in a mirror' (Calvin 1948:19).

7.The earliest compilation of the letters was mainly by Charles de Jonvilliers, who served as Calvin's secretary, under the watchful eye of Beza, now included in the Calvini Opera (Bonnet 2009:7, vol. 4).

8.'Was he a man of system?' asks Cottret (1995:327), 'the work of one of the major writers of this century of rebirth cannot be reduced to this fundamental theological treatise alone.'
Calvin does not struggle to transfer his theology into a pastoral situation. He does so without losing the sense of his conviction about the truth he is conveying and also at the expense of insensitively addressing the recipient of the letter. For that reason, he is not found to be theologically eclectic in his writing, but, as will be shown, applies basic theological guidelines, which may be usefully applied in most practical theological situations. In this sense, he seems to deliver theology as a key, practically applied with depth of insight, seldom found beyond these pages. Bonnet's collection of letters is referred to because of its availability in English and occasionally supplement them from the Opera Quae Supersunt Omnia (CO) (n.d.). ${ }^{9}$ Calvin is one of the creators of the French language with his writings as 'models of eloquence' (Bonnet 2009:11, vol. 4) indeed as Luther was for the German language.

Some historical background is provided to give a sense of the urgency and immense responsibility that Calvin shouldered in writing to so prominent a person as the Duchess of Ferrara. Also evident is the maturing of his pastoral episcopate ${ }^{10}$ in counselling as seen in his voluminous correspondence. A mark of Calvin's writing to persons in high positions was to encourage them to serve the Lord by continuing their commitment to the protestant cause (Greef 2008:199).

\section{Letters to a duchess}

The pro-evangelical cousins - Renée of France, also known as Renata the Duchess of Ferrara (-1575) and Renata di Ferrara, daughter ${ }^{11}$ of Louis 12 and Anne of Brittany, together with Marguerite of Navarre, sister of Francis I and known as Margaret of Angoulême, ${ }^{12}$ played significant roles in promoting reformational changes. In particular, Margaret was witty, exceedingly intelligent and beautiful. After the death of the queen mother, she exercised influence over her younger brother, Francis 1 (McGrath 1990:63-64, 77). Calvin recognised that these aristocrats could promote the reformation of churches in France. ${ }^{13}$ Blaisdell (1982:67) notes that, from 1542 until his death, Calvin maintained correspondence with at least 18 women, mostly of noble birth. About 60 of his letters to women survive (Blaisdell 1982:69).

The Duchess of Ferrara's court ${ }^{14}$ in Ferrara was often a place of safe refuge for those fleeing for their Protestant faith.

9.Calvin (1948:18) himself said on occasion: "I promised what for a long time i had been thinking of, to write something on the subject in the French language, that my countrymen might not be without the means of being enabled to understand.'

10.Van 't Spijker (2009:34) makes the interesting point of Calvin's stature and office: ... a felicitous description of the office he held his entire life: pastoral episcopate by virtue of instruction from the Scriptures'.

11.If Renée of France had been a man, she would have succeeded her father, Louis XII, to the French throne (Stjerma 2009:176).

12.The spelling changes are often dictated by the author of this article.

13.D'Aubigne (1863:431-432) identifies Margaret as the most eminent person to propagate the gospel and reformation in France though she never became a Calvinist and had pietistic leanings.

14.Renata followed her husband, Hercules II of Esté and a grandson of Pope Alexander $\mathrm{VI}$, in a marriage arranged for diplomatic advantage to Ferrara in 1528. At the time of Calvin's visit, she was having marital problems, taking comfort in religion (Wende 2002:47). Ferrara also managed to remain outside of the papal grip (Young 1860:62). 
Calvin ${ }^{15}$ and Du Tillet visited her court (March/April 1536) for two months in that capacity. ${ }^{16}$ Although there was little overt opposition to Rome, the undertones and mockery of pomp and superstition, though subdued, was standard fare at the time. Calvin maintained a protracted correspondence with her to the end of his life (Van 't Spijker 2009:33) though there is evidence that many of their letters did not survive (Barton 1989:61). Ferrara, Modena and Florence were all influenced by protestant doctrines (Fisher 1900:392-393). The duchess' correspondence with the reformer was most likely, because it was he who initiated her into the reformed faith for which she was to suffer and in which she persevered (Bonnet 2009:295, vol. 4). Of superior intellect, she was already 'acquainted with the Scriptures and accustomed to reverence their divine authority' (Young 1860:61) and 'sincere as a Christian'17 (p. 75).

She had been married by proxy ${ }^{18}(1515)$, but the marriage was annulled by the pope in 1516 (Young 1860:72). She suffered when her sister, Queen Claude, died in her arms after childbirth in 1524 (Young 1860:71). No doubt the reformer's subsequent reputation, the publication of his Institutes and its dedication to Francis 1, king of France and the duchess' brother-in-law, had some influence on her choice of a counsellor $^{19}$ despite the fact that the last visible picture she had of him was his hasty departure from Ferrara. ${ }^{20}$ It is clear too that, as Calvin's reputation as a reformer and pastor grew, so did his correspondence. This included some of the most influential persons of his time, and it increased as he both responded with advice and continued to solicit the aid of the rich and powerful on behalf of the reformation of the church.

Whilst it is evident that Renata suffered for her faith, ${ }^{21}$ her heart belonged to the Protestant confession (Henry 1847:325), leaning toward those who decried superstition on the basis of a reformational understanding of the Scriptures. However, the road to maintaining that confession was not without suffering and accompanied by temptations to revert back to Catholicism (Henry 1847:325-326).

15.Calvin used the pseudonym Charles d'Esperville while in Ferrara (Van 't Spijker 2009:33), and Michael Servetus used the pseudonym Villeneuve whilst in Vienne. When on trial, he claimed that he was mistaken for one Servetus (Barton 1989:62)

16.It is necessary to mention that, at the time, there was large troop movements because of tensions between Charles V and Francis I (Van't Spijker 2009:35).

17.It is likely that she had read Le Fevre's translation of the New Testament into French (1523).

18.She was not famous for her beauty. In fact, her husband, upon meeting her for the first time, is said to have exclaimed, 'But madame Renée is not beautiful' (Stjerma 2009:177).

19.At the same court, Calvin also met Anne de Parthenay, Countess of Marennes, who engaged him in theological conversations, which ultimately led to her conversion to Christ (D'Aubigne 1863:89)

20.Calvin thought that he, amongst others, was compromised when the evangelical Jehanet walked out of a traditional Good Friday service (14 April), venerating the cross at a particularly awkward time, refusing to take further part in the ceremony. This drew attention to the number of evangelicals sheltered by the Duchess at court (McGrath 1990:77). Calvin's visits to the Duchess' quarters for the purpose of guiding her and other women in studying scripture brought her religious leanings guiding her and other women in studying scripture brought her religious leaning (Young 1860:81). Consequently the reformer made haste to move on from the (Young 1860:81).
court at Ferrara.

21.Renata's court also suffered at the hands of the Catholic Inquisition (Stjerma 2009:186ff.) and for maintaining a preference for French and French culture (Stjerma 2009:180-182).
More recently, Barton (1989:229) chose to revisit her stance. He did not doubt her Christian confession and suggested that her ecumenical stance was an attempt to put focus upon Catholicism and Calvinism alike. ${ }^{22}$ This was a stance she maintained for 30 years of married life within the context of overt Catholicism, which was part of the culture and way of life in which she found herself. Though well aware of the persecutions and the risk she was taking, her conscience was clear (Young 1860:75-76, 79). Between 1528 and 1535 she had three children with her husband, Hercules 2 (Ercole 2), whom she married on 28 June 1528. She visited Venice in 1534 and heard much about reform. From that time onwards, the 'seeds of heresy' were seen to be evidently entertained by her. This gave Calvin hope that her court ${ }^{23}$ might become a beacon for the reformation in Italy (Young 1860:80). In giving refuge, she did not distinguish between protestant dissidents, Lutherans, Calvinists or Jews (Stjerma 2009:176). Exasperated, Hercules banned all Protestants from his court. He also banned his wife's French governess, Madame de Soubise, for fear that his new alliances with the pope and the emperor would be compromised. Though severely challenged, Renata soon surrounded herself with likeminded Italians. ${ }^{24}$

Sometimes her conscience would militate against her actions, but in deference to her husband, she sought to please him as far as she could. Nevertheless, Hercules allowed her to be charged as a heretic, which she resisted until she was forbidden to see her children. She recanted (1554), but consistently refused to join in any form of Roman Catholic worship. Calvin's letters to her were 'frank and imperious in tone', according to Wendel (2002:47), 'marked with frankness and respect' (D'Aubigné 1863:89). After 1548, he became her spiritual director. Upon Hercules' death, Renata returned to her estate, Montargis, in France (1560), but staying with her son Alfonso 2, the new Duke of Ferrara and an ardent papist, became untenable. At Montargis, she engaged a reformed preacher to minister on her estates to anyone who would join them. Her castle served as a refuge for those persecuted for their faith, and she is commended for this by Calvin (Bonnet 2009:314, vol. 7). He also commended her intervention on behalf of the protestant church and before his death dictated a last letter in French to her (Bonnet 2009:360, vol. 7). From his correspondence, one should also be able to discern the place this woman ${ }^{25}$ had in advancing

22. Both Protestants and Catholics claim her allegiance. Her will contained a long confession of faith, 'reading much like the Institutes of the Christian Religion in simplified form' (Barton 1989:228-229).

23.Catholic sources generally stress her piety and relationship to the church whereas Protestants stress her relationship to Calvin (Stjerma 2009:186ff.). Evidence of the careful juggling in which she was involved for most of her life so as to maintain her personal faith and the semblance of Catholic spirituality, the story is complex and should not be reduced to mere platitudes for it was intentional and the means to survive and maintain a good conscience. It is reminiscent of the challenge with which Dietrich Bonhoeffer wrestled as he faced the question 'what is truth?' the more he became involved in the plot to assassinate Adolf Hitler (Metaxas 2010:365ff.).

24.One of the most remarkable was Olympia Morato 'the marvel of her age', a prodigy who, at the age of 13 , commanded Greek, Latin and classical history, some rhetoric and philosophy and wrote poetry in the fashion of the ancients she was reading. Renata appointed her to be instructress to her daughter, Anna d'Este, who was Renata appointed her to be instructress to her daughter, Anna d'Este, who was
eight years old. Together they studied the scriptures in Greek (Young 1860:99eight years old. Together they studied the scriptures in Greek (Youn
100 She fell into disfavour with Renata and was banished from court.

25.To this end, Blaisdell (1982:69) mentions Charlotte de Laval, Madeleine de Mailly, Comtesse de Roye and her daughters Eléanore de Roye and Charlotte de Roye, Comtesse de Rouchefoucauld to name some. 
the protestant cause of the reformation (cf. Blaisdell 1982). To that end, Blaisdell (1982:77) regards his letters to the duchess as most interesting.

Calvin's letters to her reveal 'the heart-searching nature of his religious principles' (Young 1860:92). Her response to his letters revealed a consistent teachable spirit, somewhat surprising for someone who could command and demand at whim, expect others to serve and obey without so much as a murmur, whose every whim was catered for. Yet this person of rank rather submitted herself to the dictums of Holy Scripture and, for that reason, experienced difficulties equal to her privileged status. Nevertheless, Calvin had great hopes for her influence for the cause of the gospel in Italy (Bonnet 2009:121, vol. 7).

\section{Letter 1: Trouble at court, Geneva, October 1541 LXXIX}

A glimpse into Calvin's circumstances and some ecclesial changes serve to set this letter contextually. By 1541, the catholic reformation was gaining momentum, and the Societas Iseu (Jesuit order) was finally approved by Pope Paul 3 in 1540. In the same year, Calvin returned from Strasbourg to resume his ministry in Geneva on 13 September. Calvin French translation of the Institutes ${ }^{26}$ was published, and he had shortly before married a widow, Idelette de Bure. His commentary on Romans had already been published. Nevertheless, though immensely involved in drafting ecclesial ordinances at the behest of the city council, he found time to frame a letter to the Duchess of Ferrara.

In Calvin's letter to the duchess, he makes it clear that he is mindful of his own call as a minister of the faith. In principle, this knowledge set the pastoral relationship and the boundaries between them. Though mindful of her welfare and advantage, he is more interested in the fact that, due to her status, she is in a position of influence, which could be well used '... because, more than most princely persons, you are able to promote and advance the kingdom of Christ' (Bonnet 2009:296, vol. 4). Stjerma (2009:186) refers to the 'admonitory style he adopted in his pastoral care of women' evident from reproachful reminders to her in their correspondence. ${ }^{27}$ Without flattery, he acknowledges the grace she has in being a witness for God. ${ }^{28}$ There is every expectation on Calvin's part that the principle of the fear of God will continue and direct her in what he is about to address as per her letter to him.

Only then does Calvin address the trouble bothering the duchess of which he had been informed by visitors and by

26.Institution de la religion chrestienne: en laquelly est comprinse une somme de pieté, et quasi tout ce qui est necessaire a congnoistre en la doctrine de sault [translation in English].

27.The comment (Stjerma 2009:186) that Duke Ercole had no sway over her 'intellectual and religious life' is interesting.

28.There were immense dangers in a public confession of faith, even for the nobility The Duchess of Ferrara and Margueritte de Navarre chose to keep such profession private and let their actions speak for themselves (Blaisdell 1982:70).
Madame de Pons (see Bonnet 2009:297, vol. 4). ${ }^{29}$ A problem arose, because a priest at the court of Ferrara, Master François, appointed to the duchess' household, officiated at a mass after the usual service and preaching. By implication, this carried her approval, blurring the distinction between a protestant church service of worship and that of the mass. One of the ladies in her employ found that her conscience was troubling her about this, and her concerns seem to have found some resonance amongst others too. A shift occurred in the duchess' relationship to the woman. What was to be done?

Calvin professes that the matter of the Lord's Supper occupied him for some time and suggested that the Lord had given him some insight into the matter: ' ... it has pleased the Lord to reveal himself to me in Scriptures'(Bonnet 2009:297, vol. 4). However, he reveals his hesitance to speak out for the complex difficulties accompanying the matter. Yet, he is confident in his expectation that, though his exposition of the matter may as yet be incomplete, Renata will grasp the arguments and consequently submit to the truth of God's Word. As the truth of God comes to bear upon her, she will have to make a judgement call, either to submit to the truth revealed through faithful exposition, or to reject it.

Calvin's counsel is direct and explicit. He extensively justifies his comment (Bonnet 2009:298-300, vol. 4) that Master François' doctrine is not to be trusted unreservedly. The reasons for Calvin's caution are that his doctrine is sometimes swayed and adjusted to the moment and, in addition, that his personal life provides cause for concern about his relationship with God.

Following the dictum, 'after having understood the will of God, give advice' (Bonnet 2009:302, vol. 4), ${ }^{30}$ Calvin proceeds to the heart of the matter. As to the matter of joining in the saying of mass, Calvin is convinced that the duchess knows that 'mass is a sacrilege' (Bonnet 2009:300, vol. 4), but he briefly explicates the reasons for this serious judgement. To that end, he centres upon the heart of the matter: that salvation through Christ is not a ceremonial re-creation of the bloody sacrifice on the cross as the only effectual hope for the sinner. 'How much it is contrary to the Supper of Christ, I leave you to consider with yourself' (Bonnet 2009:301, vol. 4). If the consideration of what the Word of God teaches us is not sufficient, then a man-made institution becomes idolatrous. There can also not be a dichotomy between celebrating the externals of mass and divorcing it from the convictions of the heart. Calvin then refers to particular scriptural passages. He drives home the point that association with mass, by one so exalted as the duchess, could lead to the conclusion that she approves of it. Though scandal accompanies the evangel of Christ, it must

29.Anne de Pathenay was a Protestant and French, and a very close friend of the duchess. Her husband, Antoine de Pons' relationship with the duchess caused duchess. Her husband, Antoine de Pons relationship with the duchess caused some speculation, which caused a blot on her otherwise unblemished life as wife and Christian. Long before this (1543), Anne Pons was also accused of spreading
rumours about the Duke's plans to harm his wife (Stjerma 2009:183-184)

30.Bonnet states that this phrase appears in the margin of the letter in Calvin's handwriting. The phrase must not be confused with Augustine's 'If you understand it, it is not God' (si scis, deus est). 
not detract from him. It is also false to believe that any of the German protestant churches follow this practice, and there is no person of significant rank who is of the same persuasion (Bonnet 2009:304, vol. 4).

Calvin does not hesitate to pressure the duchess to commitment. Having set forth the word of God, he urges (Bonnet 2009, vol. 4):

Well, then, Madame, seeing that it has pleased the Lord God, of his goodness and infinite compassion, to visit you with the knowledge of his name, and to enlighten you in the truth of his holy Evangel, acknowledge your calling to which he has called you. (p. 304)

For the duchess not to do so would mean that she would remain in spiritual darkness and reveal her ingratitude to the Saviour. However, to do so would mean to embark upon a journey of continually growing in the knowledge of God, a journey of growth that will only cease at death. Fuller knowledge will come as God illumines and consequently, the heart and mind glorify him (Bonnet 2009:305, vol. 4). Calvin included some additional reading material for the duchess to peruse (Bonnet 2009:305, vol. 4).

\section{Letters 2-4: Support in trouble, Geneva, 6th August 1554 CCCLIV; 2nd February 1555 CCCLXXXIV; 10th June 1555 CCCCIII}

This letter was penned after Lyon Jamet, secretary to the duchess, visited Calvin in Geneva. Renata faced the greatest challenge to her faith yet. Her nephew, Henry II of France (1519-1559) and no friend of Protestants, had set his sights on conquering Italy and had expressed his dismay at the accusations of heresy, claiming that she had strayed from the faith (Blaisdell 1982:88). Having Renata of Ferrara declared a heretic ${ }^{31}$ would have had huge ramifications for all of her family, not least her children. She would have forfeited her considerable fortune, claims to her estates and their income as well as her right to titular claims. Also, she would have become a virtual recluse locked in some castle or cloister somewhere. Jamet delivered the letter (CCCLXXXIV) to Renata who was said to be capitulating under the unremitting grilling. The letter is interesting in that Calvin was greatly concerned that it might fall into the wrong hands. Therefore, it is written in general terms and relies on the recipient's knowledge of former correspondence in regards with requests made and information shared - a sort of reading between the lines.

Despite the danger Calvin comforts Renata, assuring her that he would have taken the place of François de Morel (Monsieur de Colonges), but circumstances did not permit that. Nevertheless, taking into consideration the immense pressures she was facing with regards to her Protestant faith, De Morel was the most suitable person to aid her in

31.Jesuit surveillance spies in Renata's court pressure from Rome about its suspicions concting concerning cend servitor, Ippolito Putti, and the refusal to make her children go to confession before partaking of holy communion, drove Ecole to distraction. As a consequence, sh faced the formidable inquisitor, Matthew Ory (Oriz) (Barton 1989:87-88, 92-93). doctrine and the matter of alms. ${ }^{32}$ His inconsequential birth and personal humility would not attract any unwelcome attention though he preached and taught with scriptural authority and was willing to accept her suffering as his own (Bonnet 2009:51, vol. 6). There could be no greater recommendation than to see this counsellor as 'directed to you by God' (Bonnet 2009:51, vol. 6). In addition, there was a woman of noble birth '... and what she seeks is the privilege of being able to serve God in serving you' (Bonnet 2009:51, vol. 6). Renata had requested two women to serve her. Calvin concludes his letter by commending her to God '... to the end that he may be more and more glorified in you' (Bonnet 2009:52, vol. 6). With this, he sets before her some of the principles of suffering.

By 07 September 1554, she had been declared a heretic and treated as a pariah and she recanted. Calvin wanted to communicate with her, but missed the opportunity to do so, as few could be trusted to carry his letters (Bonnet 2009:129, vol. 6). Writing to Farel (Bonnet 2009:88, vol. 6), he says, 'Overcome by threats and outrages she has fallen off. What can I say, except that an example of constancy is rare among princes?' Although Calvin knew the significance that a clear confession of faith by a noble person might have upon the masses, failure to do so did not lead him to condemn such a person. He merely pointed out that the failure to do so was an act of abdicating the responsibility that such people have towards other people by virtue of their rank. He also confirmed the value of confessing Christ, even whilst suffering for that confession (Blaisdell 1982:70).

The lack of news from her did not allow Calvin to serve as a consistent counsellor. This did, however, not prevent him from interpreting her state of peace as the devil's triumph and her recantation as compliance with the world (Bonnet 2009:130, vol. 6). Such was the effect of her recantation, he tells her, that Christians all over have shared in the shame. Enter the principles of restoration and hope. Calvin encourages her to rise from this fall so that final victory should belong to God. He calls her recantation 'backsliding', holding out a flame of hope by implying that she may still take a firm stand in future. However, should she do so, persecution will return. His counsel focussed on the growing desire that the hope all Christians have in Jesus Christ will be vindicated. Consideration of how he had suffered for sinners ensures trust when praying to Jesus '... that he is sufficient to help our infirmities, and meditate on those noble promises which are to exalt us by the hope of glory in the heavens' (Bonnet 2009:130, vol. 6). The duchess must have been greatly encouraged to read his assessment that '... the desire of glorifying God is increased in you, or at least is no wise deadened' (Bonnet 2009:130, vol. 6). Calvin also assures her that he is quashing rumours about her. ${ }^{33}$

32.The position of almoner was probably the way in which Renata was able to ensure the employ of the pastor.

33.Rumours spread by Mark, the Italian (Bonnet 2009:130, vol. 6). 
In his letter of 10 June, Calvin recognises that Renata's continuing struggle to maintain a clear confession of her faith is given to her as an experience of a diabolical trial, but should ultimately be seen to be the Father's test (Bonnet 2009:188, vol. 6). Her suffering is to advance the cause of God, not her own relief and comfort. Yet this does not preclude trust in him and learning about the compassion of God. There is to be a daily 'advance in the right path' regardless of weakness and few signs of progress, based on the promises of God that sustain not some haphazard random advance (Bonnet 2009:189, vol. 6).

\section{Letter 5-6: Support in continuing in the faith, 20th July 1558 DV; Geneva, 5th July 1560 DLXVIII}

Deep concern is expressed for the duchess' continued spiritual walk in the faith. She should, with conscious effort, persist in growing her faith, with or without a counsellor, though the latter would prove to be of benefit (Bonnet 2009:448, vol. 6). Calvin is concerned that she should stand against the wiles of the devil and his attacks. However, two years later Calvin confesses his failure to find the right counsellor for her, one that will fit, take her position into consideration and wisely proceed in spiritual matters and not be driven by excessive zeal (Bonnet 2009:121, vol. 7). By this time her husband, the Duke of Ferrara, Ercolle d'Este, had died.

Having heard that she faced opposition to the cause of the gospel within her own household, he counsels her to remove such persons and follow the example of David (Ps 101), even at the risk of suffering their slander as a consequence (Bonnet 2009:448, vol. 6). Calvin is cautious to refer in general to David and to avoid specific texts, which may presumably be open to misinterpretation. Safety lay in the grander narrative in Calvin's absence and letter writing. To follow David would be to entrust judgement to God and to trust him to weigh the intentions of all acts. Similarly, the way of Christ may also be the way of retreat. Calvin reminds her of Peter who had to go where he did not want to go, making the point that opposition accompanies all who follow Jesus. Finally Calvin refers her to the contemporary struggles of the Marquis de Vico with an unbelieving wife '... who loves him in such sort, as to draw him on, if she could to perdition' (Bonnet 2009:449, vol. 6).

On her husband's deathbed, Renata took an oath not to communicate with Calvin any longer - an oath she did not keep. Calvin regarded it his pastoral duty to inform her that her oath compares to that of Herod, the fulfilment of which was accompanied by excessive adherence (Bonnet 2009:122, vol. 7). Ever concerned for the cause of Christ and the church, he expresses regret at her decision to leave Italy for France, confirming the underlying principle that one should serve God in the place where it pleased him to place you in the first place. Calvin cannot see how the move will advance the cause of God and asks her to consider her motives (Bonnet 2009, vol. 7):

I desire your prosperity, Madame, as much as possible; but if the elevation and grandeur of the world should prevent you from approaching to God, I should be a traitor to your interests in making you believe that black is white. (p. 122)
Calvin shows that his counsel also extends to mundane matters. Though he formerly advised her to entrust burdensome administrative tasks to suitable persons and in her pursuit of good works to remain 'callous to censure while doing good' (Bonnet 2009:449, vol. 6; p. 123, vol. 7), he now advised her to take a hand in the management of matters if she were to relocate. Wherever the Christian may relocate, the follower of Jesus Christ only finds eternal rest in him at the appropriate time. Meanwhile as a widow, she had more freedom to serve him until the day appointed for her.

\section{Letter 7: Call to influence her daughter in support of the Protestant cause, Geneva, February 1562 DCXXIV}

The duchess' daughter, Anna d'Este ${ }^{34}$ (1531-1607), was married to Francis, Duke of Guise (1519-1563) in 1548. The duke, an ardent Roman Catholic, foiled a first attempt to assassinate him in 1560 and suppressed the plot brutally, which caused Gaspard de Coligny to speak against him. Though Anne, Duchess of Guise, followed her mother's faith covertly, did so with more ambivalence. The Guise family consistently opposed Christianity ${ }^{35}$ and joined others in the process. "They verily think that it is their duty to banish all Christianity out of the world' (Bonnet 2009:261, vol. 7).

The church, Calvin reminds Renata, is God's, who is its protector, implying that such opposition would be to invoke the God of the Church as enemy. To that end, he exhorts Renata to exercise whatever parental authority and powers she had to caution Anne to moderation, implying that Anne should bring to bear whatever influence she had upon the Duke of Guise.

\section{Letter 8-9: Good works Geneva, 10th May 1563 DCXLVII; 8th January 1564 DCLXIII}

Despite threats from all sides, Renata welcomed anyone seeking help and asylum at Montargis, her estate. In light of her previous track record of capitulating in the face of strong demand and opposition, she persisted to extend Christian hospitality. Calvin is convinced that this was possible because '... God has strengthened you during the rudest assaults ... not being ashamed to bear the opprobrium of Jesus Christ' (Bonnet 2009:313, vol. 7). He wants her to consider that the trials of her younger days have prepared her to face the same in old age (Bonnet 2009, vol 7):

I cannot do you higher honour than in expressing myself thus, to commend and recognize the humanity which you have exercised towards the children of God who found a refuge with you. (p. 314)

However, Calvin also needs to deal pastorally with two household matters. Renata is harbouring an adulterer at Montargis, a blight, which will cause the ungodly to revel

\footnotetext{
34.She never committed herself to either Catholicism or Protestantism, not following the Calvinist line and overt expression of faith as her mother did. In fact, she seemed to apply herself to both though her children and grandchildren were outspoken Roman Catholics.
}

35.Read Protestant/Calvinist/Reformed/non-Catholic. 
in gossip (Bonnet 2009:315, vol. 7). The matter needs to be dealt with. In that, she is counselled to keep a strong hand upon her household, exercising good discipline so as to maintain blamelessness. ${ }^{36}$ To avoid scandal above all signifies submission to the Son of God (Bonnet 2009:349, vol. 7). Such discipline is not only the prerogative of the head of the household, but according to the reformed tradition, also of the consistory. In addition, he reminds her of the spiritual onslaught of the devil (Bonnet 2009:350-351, vol. 7). The second matter is a promise she made to an old servant to provide for his daughter when she came of age to marry (Bonnet 2009316, vol. 7). Renata was famed for her generosity.

\section{Letters 10-11: Matter of forgiveness and right judgment, Geneva, 24th January 1564 DCLXIV; Geneva, 4th April 1564 DCLXVI}

In 1562, the Duke of Guise's command led to the bloody massacre of Huguenots, worshipping at Vassy. Though Guise escaped one attempt to assassinate him, he did not escape the second at Orléans in 1563 by Huguenot Jean de Poltrot ${ }^{37}$ (c. 1537-1563). It was primarily this event that brought the person of the late duke and the name of Guise into disrepute. This deeply affected the Duchess of Ferrara. Her daughter, Anne, Duchess of Guise, held Gaspard de Coligny (15191572), leader of the Huguenots, responsible for many years. He was, however, eventually declared innocent by the King's council in $1566 .^{38}$

Just months before Calvin's death, he again wrote to the Duchess of Ferrara. In this matter, Calvin has very little preamble and immediately goes to the matter at hand. The duchess is disturbed by, in her opinion, the continual harshness and lack of charity by Christians in their references and discussions of her late son-in-law, and she is appealing to Calvin to intercede for and advise her. The truth is, as Calvin reminds her, that the duke did kindle a conflagration against a good cause, presumably referring to the congregation in the process of worshipping God (Bonnet 2009:354, vol. 7).

Calvin exhorts the duchess to take, as it were, a step back from the situation and to consider the situation rationally from a biblical perspective (Bonnet 2009:352-353, vol. 7). $\mathrm{He}$ is concerned to set the argument on the firm ground of correct and reasonable understanding of his exegesis of Psalms. Getting straight to the point, he firmly corrects her reinterpretation of his counsel in regards with David's example as guide in dealing with enemies. David's hatred centred upon moderation to the extent that he was a type of Christ. Calvin exhorts her to refer to his commentaries on the Psalms for further instruction through the Holy Spirit. This is amply confirmed by Jesus who rebukes his disciples when

36.Though applied to the examination of people before partaking in the Holy Communion, the principle was that it was for the well-being of the church. It was not regarded as essential to the church as the notae ecclesiae (Dreyer 2010:17).

37. Under torture, in the midst of much confusion and contradiction, he mentioned the name of Coligny, which was deemed evidence of the admiral's complicity in the assassination of the Duke of Guise.

38. Matters came to a head when Coligny died in 1572, followed by the fanatical massacre on St. Bartholomew's Day. they vengefully wanted to bring down fire in the manner of Elisha. A spirit other than the one at work in Elisha was at work in this call (Bonnet 2009:353-354, vol. 7).

Sound biblical knowledge was crucial for Calvin. In its corpus, the will of God may be discerned and is the cause that awakens the soul. For that reason, the duchess is reminded that she is not the only one to have suffered '... anguish and bitterness during these horrible troubles that have fallen out' (Bonnet 2009:354, vol. 7). Calvin admits that, though he prayed for the duke's salvation, he also asked God for his removal if not converted and admits that he personally prevented suggested assassination attempts upon the duke's life at times (Bonnet 2009:354, vol. 7). Nevertheless, in principle 'unless one had some certain and infallible mark of his reprobation', no one has the right to pronounce damnation upon the departed duke. Equally no one can claim bliss in the afterlife for the late King of Navarre. All, regardless of station, will appear before the same Judge for account. Such distinctions blur the reality of the persons, failing to take a holistic approach and tend to confuse prayer (Bonnet 2009:354, vol. 7). To avoid such blurring is to admit that prayer for someone does not admit someone to the church or put such a person into God's favour, as Calvin illustrates by referring to the case of Jeanne d'Albret, queen of Navarre, and the matter of praying in public for her husband 'who had fallen from us' (Bonnet 2009:355, vol. 7). It was a most sensitive matter, more so in that he was her husband whereas the Duke of Guise was the duchess' son-inlaw. Calvin counsels that care must be exercised in an attitude of 'moderation and sobriety' (Bonnet 2009:355, vol. 7), leading the queen to submit to the greater matter of God's glory.

Because of the absence of facts, another matter about some conflict between persons associated with the duchess' household (Bonnet 2009:360-361, vol. 7) is not clear enough for Calvin to make any serious pronouncement. The only point he makes is that the self-interest in behaviour reported to him does not equate to what one may expect of Christians and clouds the mind on what may be the correct behaviour (Bonnet 2009:356, vol. 7).

Calvin's pressure to commitment is evident in these letters. Temptation to hate and hatred, in this writer's opinion, seems to underlie most of the issues dealt with in this letter. A general maxim of correct behaviour would be to emulate that of Christ, who always sought to do good and so exposed evil. Hatred has no place in such behaviour. It leads to prejudice and obfuscates the love for the unworthy. To that, the duchess is now urged, with God's strength, to commit herself (Bonnet 2009:357, vol. 7). Her example will be evident to all and confuse those whose practice of 'hypocrisy and dissimulation' towards her will be evident. A final example of one whose character remains unblemished is that of Admiral Gaspard de Coligny (1519-1572), who was deceived and died for his error. ${ }^{39}$

Despite this letter to the duchess, the next letter to her (Bonnet 2009:360-361, vol. 7) from Calvin indicates that she

39.The letter of 24 January 1564 ends abruptly without furnishing further details. 
misinterpreted his counsel. He tells her of his great struggles with his health, the purpose for his brother Antoine's hand in writing to her. Without mincing words, he suggests that her confused emotions 'shut the door on reason and truth' (Bonnet 2009:360, vol. 7). At the same time, he commends her for her example. She must know that, despite her close connection to the Duke of Guise, nothing has caused her to waiver in her faith, endearing many to her (Bonnet 2009:361, vol. 7). Hearsay brought the news that the duchess' niece, Margaret of France (1523-1574), was considering a public declaration of her sympathies and commitment to the Protestant cause. Calvin reminds the duchess that her niece is timid and so her aunt needs to encourage her in this profession, trusting ' ... that you will do your whole duty according to your zeal for having God more and more served and honoured' (Bonnet 2009:361, vol. 7)

\section{Some pastoral guidelines applied}

In the words of Blaisdell (1982):

Calvin seems to have reserved no more sympathy for women than for men. While he may have thought of woman as the weaker vessel, in spiritual matters he treated her as if she were equal to man. (p. 74)

For that reason, the manner of pastoral care, identified from his letters to Renata, may equally apply to any person.

From the above study, it is obvious that Calvin's pastoral care cannot easily be reduced to a set of ordered, structured guidelines or even principles. Even in letter writing, such a reduction would have to take into account the complexity of the situation and of the person addressed. Consequently, there does not seem to be a single formula. Notwithstanding, some general guidelines will be identified as they were the most obviously employed by Calvin in serving as the Duchess of Ferarra's counsellor:

1. Thoughtful consideration of her plight and requests for Christian companions led Calvin to consider that the essential traits necessary for a Christian are clear doctrinal guidance and commitment to the cause of standing by a fellow Christian.

2. Rather than being judgemental when dealing with matters such as her backsliding and rash taking of an oath, these hurdles should be seen as obstacles to be dealt with by God's compassion and to stir one towards a victory of faithful obedience to Christ.

3. There is not much to gain from comparing infinitesimally small advances with significant advances in faith. Rather, trust in the promises of God should be pre-eminent, for both reflect the work God has initiated and will bring to completion.

4. A change in circumstances requires thoughtful consideration of options, not least of how one might best serve the gospel cause even to the extent of bringing parental influence to bear upon a married daughter.

5. There is no spiritual caution if the role of the devil and his wiles is not touched upon.
6. A clear understanding of forgiveness lies in the fact that it is God who forgives regardless of anyone's commendation or condemnation.

\section{Conclusion}

From the above, it is reasonable to expect any reformed counselling to at least include some of the insights of Calvin when applying the guidelines discerned in his pastoral care. Proceeding from reason and intelligibility to the honour and glory of God underlies all counselling, because, for Calvin, doctrine transforms the whole person, evident in holy living. Whatever guidelines or principles are employed, any Christian counsel should seek to keep the glory of God in mind.

\section{Acknowledgements Competing interests}

The author declares that he has no financial or personal relationship(s) that may have inappropriately influenced him in writing this article.

\section{References}

Baker, D., 2011, 'Corresponding Keats: A symposium on Keats', The Kenyon Review 33(4), 151-160.

Barton, F.W., 1989, Calvin and the duchess, Westminster/John Knox Press, Louisville. Beza, T., 1836, The life of John Calvin, transl. F. Sibson, Philadelphia.

Blaisdell, C.J., 1982, 'Calvin's letters to women: The courting of ladies in high places', Sixteenth Century Journal 13(3), 67-84. http://dx.doi.org/10.2307/2539605

Bonnet, J. (ed.), 2009, John Calvin: Tracts and letters, vol. 4-7, letters, transl. D. Constable, The Banner of Truth Trust, Edinburgh.

Calvin, J., 1948, Commentary on the book of Psalms, transl. J. Anderson, vol. 1, William Eerdmans \& Co, Grand Rapids.

Cottret, B., 1995, Calvin, a biography, William B. Eerdmans Publishing Company, Grand Rapids.

D'Aubigné, J.H., 1863, History of the reformation in Europe in the time of Calvin, vol. 2: Geneva and France, Longman, Green, Longman, Roberts \& Green, London.

Dreyer, W.A. 2010, 'From Noyon to Geneva', In die Skriflig 44, suppl. 3, 1-22.

Fisher, G.P., 1900, The Reformation, Charles Scribner's Sons, New York.

Garfield, S., 2013, To the letter: A celebration of the lost art of letter writing, Gotham books, Penguin Group, New York.

Greef, W., 2008, The writings of John Calvin: An introductory guide, transl. L.D. Bierma, Westminster John Knox Press, Louisville.

Henry, D.P., 1847, Het leven van Johannes Calvijn, den grooten hervormer, in twee deelen, Van der Meer \& Verbruggen, Rotterdam.

Johnson, T.C., 1900, John Calvin and the Genevan reformation, The Presbyterian Committee of Publication, Richmond.

Lane, A.N.S., 1987, 'Guide to recent Calvin literature', Vox Evangelica 17, 35-47.

McGrath, A.E., 1990, A life of John Calvin: A study in the shaping of western culture, Blackwell, Oxford.

Metaxas, E., 2010, Bonhoeffer, pastor, martyr, prophet, spy: A righteous gentile vs. the third reich, Thomas Nelson, Nashville.

Opera Quae Supersunt Omnia, n.d., the Hekman Library site, Post-reformation digita library: Reformed authors, viewed 27 January 2014, from http://libguides.calvin. edu/content.php?pid $=47579 \&$ sid $=422438$

Stjerma, K., 2009, Women and the reformation, Blackwell Publishing, Oxford.

Van't Spijker, W., 2009, Calvin: A brief guide to his life and thought, transl. L.D. Bierma, Westminster John Knox Press, Louisville.

Wendel, F., 2002, Calvin: Origins and development of his religious thought, transl. P. Mairet, Baker Books, Grand Rapids.

Witte jr., J. \& Kingdon, R.M., 2005, Sex, marriage, and family in John Calvin's Geneva, vol. 1: Courtship, engagement and marriage, Wm. B. Eerdmans Publishing Co., Grand Rapids.

Young, M., 1860, The life and times of Aonio Paleario or a history of the Italian reformers in the sixteenth century, vol. 2, Bell \& Daldy, London. 